\title{
Neuroimmun-moduláció az emésztőcsatorna nyálkahártyájában
}

\author{
Fehér Erzsébet dr. - Altdorfer Károly dr.
}

Semmelweis Egyetem, Általános Orvostudományi Kar, Anatómiai, Szövet- és Fejlődéstani Intézet, Budapest

\begin{abstract}
Az enteralis idegrendszerben termelt neuropeptidek szerepet játszanak az immunsejtek múködésében, részt vesznek a gyulladás fokozásában és annak csökkentésében. Összefoglaló munkánkban azt elemeztük, hogy a gyulladás milyen hatást fejt ki az idegelemek és immunsejtek neuropeptid-tartalmára. Gyulladásos mintákat (human gastritis, állatkísérletes indukált colitis, sztreptozotocinnal indukált diabetes mellitus) és kontrollpreparátumokat hasonlítottunk öszsze. A neuropeptid-tartalmú idegrostok és immunsejtek mennyiségét vizsgáltuk (immunhisztokémia, konfokális lézermikroszkópia, elektronmikroszkópia), esetleges közeli kapcsolatokat kerestünk. Gyulladásos folyamatokban (gastritis, kísérletes colitis, diabetes mellitus) a substance P, neuropeptid Y és vasoactiv intestinalis peptid pozitív idegrostok mennyisége szignifikánsan megemelkedett, s ezzel párhuzamosan a nyálkahártyában lévő immunkompetens sejtek (lymphocyták, plazmasejtek, hízósejtek) száma szintén jelentős mértékben megnőtt ( $\mathrm{p}<0,001)$. Gyulladás hatására az immunsejtek aktiválódtak és pozitívan jelölődtek substance $\mathrm{P}$, neuropeptid $\mathrm{Y}$ és vasoactiv intestinalis peptid elleni antitestekkel. Kontrollanyagban sohasem sikerült nagyon közeli idegrost-immunsejt közötti morfológiai kapcsolatot kimutatni, viszont gyulladás hatására számos immunsejt mellett található idegrostköteg, ahol az idegrostok egy része immunpozitivitást mutat substance P-re, neuropeptid Y-ra és vasoactiv intestinalis peptidre. Konfokális lézermikroszkóppal kettős jelöléssel bizonyítottuk, hogy tumornekrózisfaktor-alfa- és nukleárisfaktor-kappa-B-pozitív immunsejtek egy részében a substance P kolokalizációban fordul elő. A tumornekrózisfaktor-alfa és nukleárisfaktor-kappa-B-pozitív immunsejtek mennyiségének emelkedése korrelált (párhuzamosan emelkedett) a substance P-immunreaktív idegrostok mennyiségének növekedésével human gastritisben. Eredményeink alátámasztják, hogy substance P-antagonisták vagy neuropeptid Y és vasoactiv intestinalis peptid alkalmazása az utóbbi évtizedben új terápiás lehetőség lehet a krónikus gyulladások kezelésére.
\end{abstract}

Orv Hetil. 2020; 161(35): 1436-1440.

Kulcsszavak: enteralis idegrendszer, neuroimmun-moduláció, neuropeptidek, gyulladás

\section{Neuroimmunomodulation in the mucosa of the alimentary tract}

Neuropeptides synthetised in the enteric nervous system can change the function of the immunocells and play a role in inflammatory processes. In our review the effects of inflammation on the neuropeptide content of nerves and immune cells were compared. Inflamed tissue samples (human gastritis and animal models with experimental colitis and streptozotocin-induced diabetes mellitus) were examined. The number and contacts of neuropeptide-containing nerves and immune cells were studied using immunohistochemistry, confocal laser microscopy and electronmicroscopy. In inflammation, the number of substance $\mathrm{P}$, vasoactive intestinal polypeptide and neuropeptide $\mathrm{Y}$ nerve fibres was increased significantly in parallel with the strongly increased number of immunocompetent cells $(\mathrm{p}<0.001)$. In inflammatory diseases, a large number of lymphocytes and mast cells were also positive for these neuropeptides. Very close morphological relationship between substance P and neuropeptide Y immunoreactive nerve fibres and immunocells could be demonstrated only in inflamed mucosa. Some of the substance P immunoreactive immunocells were also immunoreactive for tumor necrosis factor alpha and nuclear factor kappa B in the case of inflammation. The increased number of tumor necrosis factor alpha and nuclear factor kappa B immunoreactive immune cells correlated with the increased number of substance P-containing nerve fibres. Substance P, vasoactive intestinal polypeptide and neuropeptide $\mathrm{Y}$ released from nerve fibres and immunocells can play a role in inflammation. Our results suggest that using substance $\mathrm{P}$ antagonists or vasoactive intestinal polypeptide and neuropeptide $\mathrm{Y}$ peptides might be a novel therapeutic concept in the management of inflammation.

Keywords: enteric nervous system, neuroimmunomodulation, neuropeptides, inflammation

Fehér E, Altdorfer K. [Neuroimmunomodulation in the mucosa of the alimentary tract]. Orv Hetil. 2020; 161(35): $1436-1440$.

(Beérkezett: 2020. március 16.; elfogadva: 2020. április 6.) 


\section{Rövidítések}

CGRP = calcitonin gene-related peptide IFN = interferon; IFN $\gamma=$ interferon-gamma; IL8, IL17 = interleukinek; NFkB = nukleárisfaktor-kappa-B; NK-sejt $=$ natural killer sejt; NPY = neuropeptid Y; PACAP = pituitary adenylate cyclase-activating polypeptide; SP = substance P; TNBS = trinitro-benzolszulfonsav; TNF $\alpha=$ tumornekrózisfaktor-alfa; VIP $=$ vasoactiv intestinalis polipeptid

Gyulladás hatására a nyálkahártyában lévő neuroimmunkapcsolatok változásai az immunitással és az oxidatív stresszel függnek össze. A közleményben a szerzők az emésztőrendszer nyálkahártyájában zajló neuroimmunmoduláció morfológiájával kapcsolatos eddigi munkásságukat foglalják össze.

Az emésztőrendszer különböző krónikus gyulladásai - így a gastritis, a colitis ulcerosa, a Crohn-betegség mindig megváltoztatják az emésztőrendszer múködését és a szervezet immunitását [1]. A gyomor-bél rendszer gyulladása megváltoztatja a nyálkahártya barrierfunkcióját, a felszívódást, a motilitást, ami fájdalommal és hasmenéssel jár. A szájüregi gyulladásoknál gingivitis, glossitis, az ízérzés zavara, leukoplakia és szájüregi tumorok alakulhatnak ki. A gyulladás következtében az enteralis idegrendszer is megváltozik, az idegrostok száma a gyulladás korai szakaszában szignifikánsan megemelkedik, míg hosszan tartó gyulladásnál idegrostnekrózis figyelhető meg [2-5].

Általánosan elfogadott tény, hogy az idegrendszer a perifériás gyulladás patofiziológiájában döntő szerepet játszik, és számos gyulladásos megbetegedésben vesz részt. Az idegrendszer nemcsak a gyulladás kezdeményezésében és fenntartásában játszik szerepet, hanem annak csökkentésében és eliminálásában is. A neuropeptideknek különösen nagy szerepet tulajdonítanak ebben a folyamatban. Yoo és Mazmanian [6] összefoglaló munkájában a neuropeptidek mellett a bélben található baktériumok jelentőségére is felhívta a figyelmet, melyek szintén befolyásolják a nyálkahártya neuropeptidmennyiségét és immunitását.

Humán- és állatkísérletes vizsgálatok kimutatták, hogy a primer szenzoros neuronok részt vesznek a perifériás gyulladás patogenezisében. A SP, a NPY, a VIP és a szomatosztatin a legfontosabb neuropeptidek, melyek részt vesznek az idegrendszer és az immunrendszer közötti kapcsolatban és a nyálkahártya gyulladásos folyamataiban. Ezen neuropeptidek befolyásolják a fagocitózist, a reaktívoxigén- és nitrogén-szabadgyökök termelését és egyéb pro- és antiinflammatorikus molekulák felszabadulását. A SP-, NPY- és VIP-immunreaktív idegrostok száma szignifikánsan megemelkedett különböző gyulladásos folyamatoknál a kísérleti állatokban és betegeknél is $[2,3,6]$. Már régóta ismert, hogy a nociceptiv idegrostok antidromos stimulációjára SP és CGRP szabadul fel, és „axonreflex” útján „neurogén gyulladás”-t okoz. Tehát a neurogén gyulladásban a SP és a CGRP fájdal- mat, hyperalgesiát és az erek vasodilatatióját idézi elő [7-9], következetesen ezen a területen bőrvörösödés és ödéma alakul ki. A gyulladásos folyamatokban elsősorban a SP és a CGRP befolyásolja - a többi neuropeptid mellett - a mononukleáris és a polimorfonukleáris leukocyták kemotaxisát, a makrofágok és lymphocyták proliferációját és gyulladásos mediátoraik szekrécióját is. SP- és neurokinin-1-receptorok hatására a T-lymphocytákban fokozódik az IL17- és az IFN-szintézis.

rasuda és mtsai [10] összefoglaló munkájukban leírták, hogy a hosszú ideig tartó diabetesben az idegrostok regenerációs képessége csökkent mind a diabeteses humán, mind a kísérleti állatokban. A hosszan tartó diabeteses modellek esetén - az irodalomban leggyakrabban használt modell ( 6 hónap $<$ ) - a szerzők a perifériás idegrostokban jelentős szerkezeti elváltozást írnak le, különösen a mozgató- és érzőidegek múködésének kiesését, axondegenerációt, axonzsugorodást és demyelinisatiót demonstráltak. Szerintük a diabetes mellitusban valószínúleg az idegrostok regenerációja a degenerációval párhuzamosan folyik, ami befolyásolja az idegfunkciókat és azok patológiáját. A diabetes mellitus egyik legfontosabb késői szövődménye a neuropathia diabetica, amely az összes idegrostot érinti, így a mozgató és érző idegrostokon túl a vegetatív idegrendszer múködése is károsodik.

A hízósejtek és az idegrostok közvetlen kapcsolatát már korábban is számos kutató bizonyította [11]. A neurogén gyulladás hatására a hízósejtek degranulálódnak, és az általuk termelt számos vasoactiv, proinflammatorikus anyag és nociceptiv mediátor - beleértve a hisztamint, a citokineket és a proteolitikus enzimeket - szöveti gyulladást okozhat [12-14]. A szerzők [12-14] azt is feltételezik, hogy a hízósejtek által termelt bioaktív anyagok károsítják a mellettük található idegrostokat is. Ezzel magyarázzák, hogy a gyulladásos bélbetegségekben a hízósejtek fokozott degranulációja és a hyperplasia mellett gyakori az axonalis nekrózis is. Különböző káros hatásokra, így gyulladásra az immunkompetens sejtek (lymphocyták, makrofágok, hízósejtek, eosinophil granulocyták) szintén termelhetnek neuropeptideket (SP, NPY, VIP) [15-17].

\section{Módszer}

Gyulladásos mintákat (human gastritis, állatkísérletes indukált colitis, sztreptozotocinnal indukált diabetes mellitus) hasonlítottunk össze kontrollpreparátumokkal. Kutatásunkban a neuropeptid-tartalmú idegrostok és immunsejtek mennyiségét és esetleges közeli kapcsolataikat vizsgáltuk immunhisztokémia, konfokális lézermikroszkópia és elektronmikroszkópia segítségével.

\section{Saját kutatási eredményeink}

Saját kísérleteinkben igazoltuk, hogy az emésztőrendszer nyálkahártyájában bármilyen gyulladás hatására (human gastritis, TNBS-sel indukált colitis, sztreptozoto- 


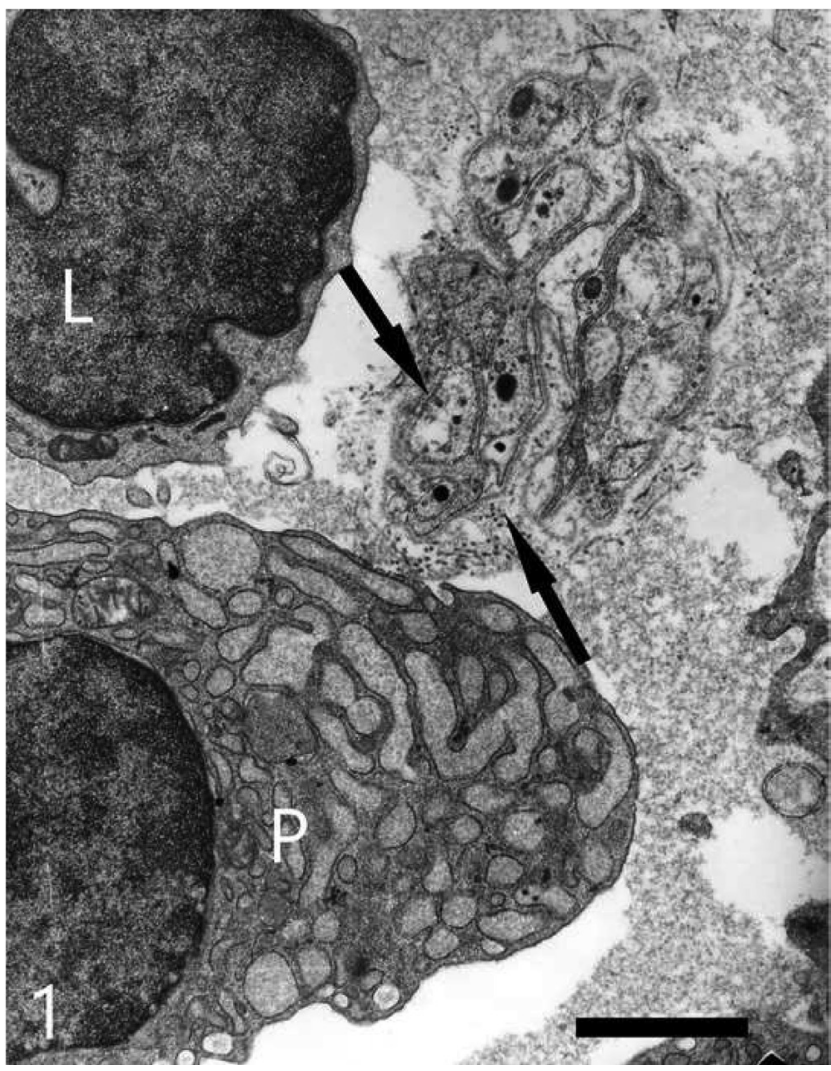

\begin{tabular}{l|l} 
1. ábra & Elektronmikroszkópos felvétel gyulladt vékonybél nyálkahártyá-
\end{tabular} jából. Nyilak jelzik az idegrostköteget egy lymphocyta (L) és plazmasejt $(\mathrm{P})$ közelében. Lépték $=1 \mu \mathrm{m}$

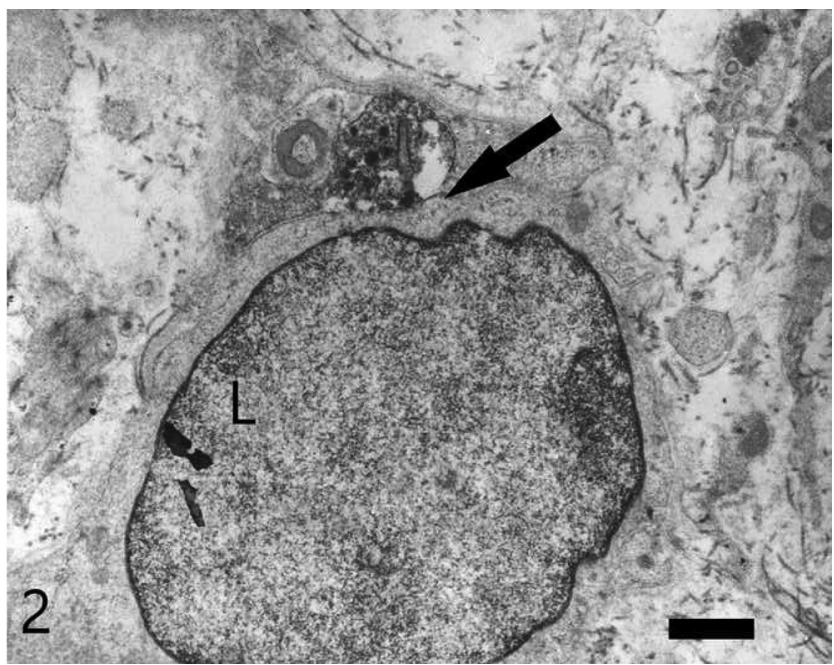

2. ábra

Nyíl jelzi a SP-immunreaktív idegrostot a lymphocyta (L) mellett közvetlenül. A közöttük lévő rés $20 \mathrm{~nm}$. Az idegrostban számos szinaptikus vesicula figyelhetô meg. Lépték $=1 \mu \mathrm{m}$

$\mathrm{SP}=$ substanc $\mathrm{P}$

xinnal indukált diabetes mellitus) a neuropeptid-tartalmú idegrostok száma szignifikánsan megemelkedett $[2,15$, 18, 19]. A varicosus idegrostok sûrü hálózatot alkotnak a hám alatt, a Lieberkühn-kripták között, valamint a gyomor mirigyei között. A kontrollállatokban a lymphocyták száma 4,7 $\pm 2,5 / 1000 \mu^{2}$ volt, míg szteptozotocin indukálta diabetes mellitusban számuk szignifikánsan

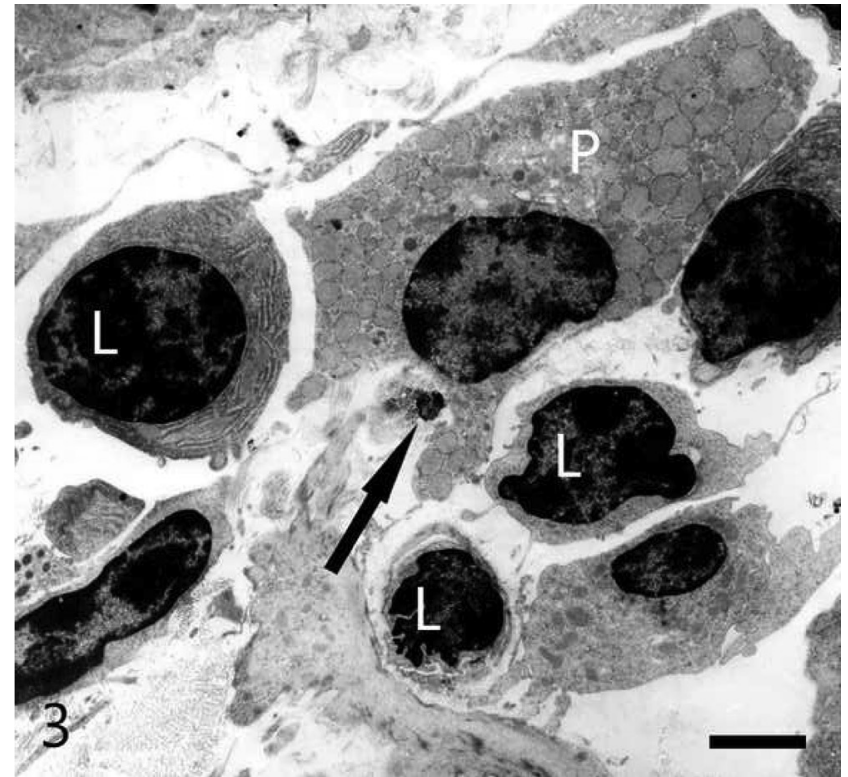

3. ábra

VIP-immunreaktív idegrost (nyíl) a plazmasejt (P) mellett gyulladt gastritises gyomor nyálkahártyájában $(\mathrm{L}=$ lymphocyta $)$. Lépték $=1 \mu \mathrm{m}$

VIP = vasoactiv intestinalis polipeptid

megemelkedett: $32,3 \pm 2,5 / 1000 \mu^{2} \quad(p<0,001)$. Kontroll-vékonybélnyálkahártyában sohasem sikerült közvetlen idegrost-immunsejt kapcsolatot megfigyelni, gyulladás hatására viszont a lymphocyták 44\%-a, a hízósejtek 12\%-a közvetlen morfológiai kapcsolatban található az idegrostokkal. Elektronmikroszkóppal a közöttük lévő szinaptikus rés kisebb, mint $1 \mu \mathrm{m}$, néha $20 \mathrm{~nm}$ (1., 2., 3. és 4. ábra). Az immunreaktív idegrostok számos szinaptikus vesiculát és egy-egy mitokondriumot tartalmaztak (2. és 4. ábra). A belőlük felszabaduló neuropeptidek diffúzióval elérhetik a mellettük lévő effektor sejteket, és így hatnak a közvetlen kapcsolatban lévő immunsejtekre, befolyásolják azok citokintermelését. Korábbi vizsgálataink bizonyították, hogy a TNF $\alpha$ és NFkB immunjelölt lymphocyták és hízósejtek száma szignifikánsan megemelkedett gyulladás hatására human gastritisben $[20,21]$; az emelkedés korrelált a SP-pozitív idegrostok számának emelkedésével.

Gyulladás hatására az immunsejtek is pozitívan jelölődtek egyes neuropeptidekre, így SP-re, VIP-re és NPYra, ami feltételezi, hogy ezek a sejtek is képesek termelni és szekretálni ezen neuropeptideket, melyek tovább hatnak a közelükben lévő idegrostokra és más immunsejtekre. Ezáltal befolyásolhatják a gyulladás kimenetelét, tovább fokozva a gyulladást, vagy részt vehetnek annak eliminálásában.

Korábbi vizsgálatainkban immunhisztokémiai vizsgálattal, konfokális lézermikroszkópiával és elektronmikroszkópos vizsgálatokkal SP-, VIP- és NPY-pozitív immunsejteket mutattunk ki különböző emésztőrendszeri gyulladásokban $[16,19,20]$. Egyes SP-immunreaktív lymphocyták és hízósejtek szintén immunreaktivitást mutattak TNF $\alpha$-ra és NFkB-ra is (5. ábra), ami bizonyít- 


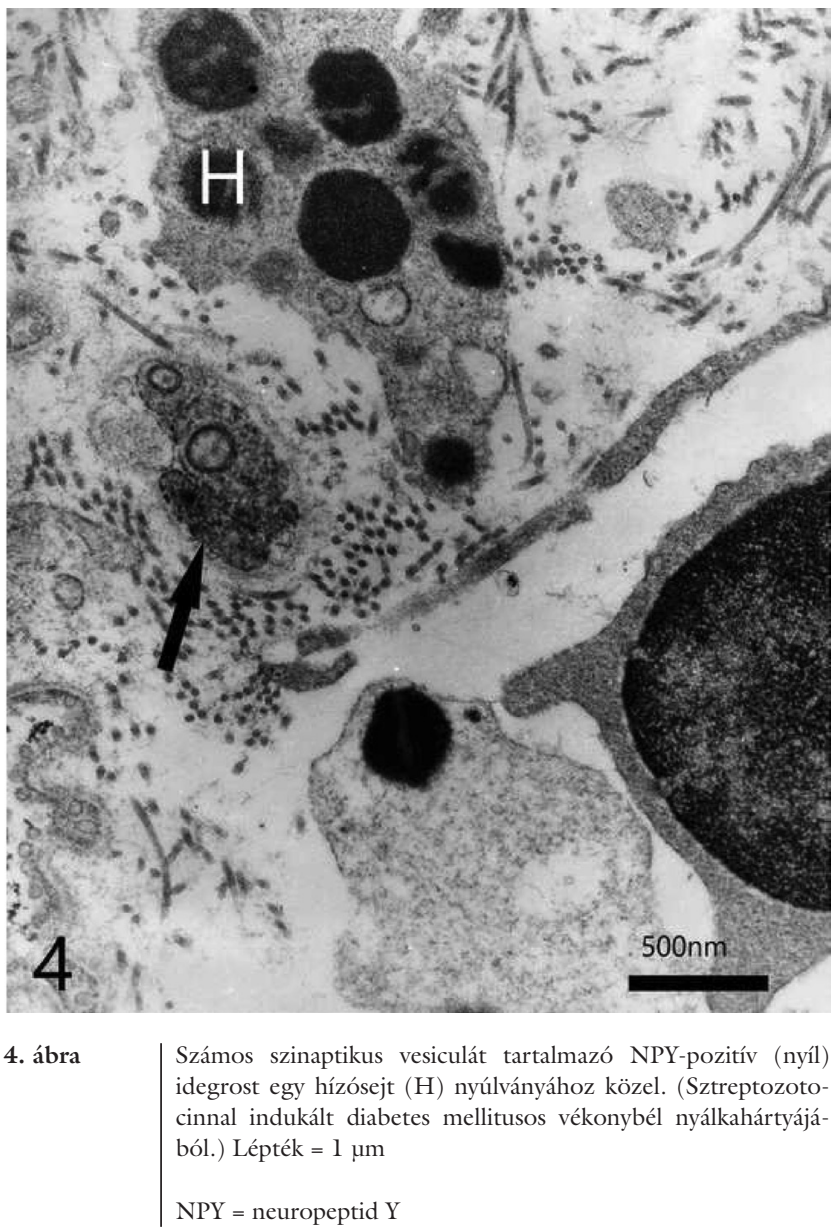

ja, hogy ezen immunsejtekben a SP kolokalizálva található a gyulladásos citokinekkel. Feltételezhetôen a belőlük kiürülő neuropeptidek és citokinek tovább fokozzák a gyulladást, aktiválva más immunsejteket és idegrostokat.

\section{Következtetések}

A SP a tachykinin-1-receptorhoz kötődve fokozza a gyulladásos citokinek termelését, így a TNF $\alpha$ és az IL8 termelését, és aktiválja a NFkB-t [21]. Az aktivált NFkB számos gén múködését befolyásolja, többek között a sejtosztódást, a sejtek migrációját, az angiogenezist és a daganatos sejtek metasztatizálását [22-24]. A SP és neurokinin1-receptor másik hatása, hogy megemeli a T-lymphocytákban az IFN $\gamma$ és az IL17 termelését, és ezáltal fokozza a gyulladásos folyamatokat [17]. Neurokininl-receptor-antagonistákkal sikerült csökkenteni kísérleti állatokban a colitist [25]. A különböző gyulladásokban az aktivált immunsejtekben fokozódik számos citokin és neuropeptid szekréciója, ezáltal direkt és indirekt módon visszahatnak a nyálkahártyában lévő idegrostokra, ami tovább indukálja az immunsejtek múködését.

Újszülött egerekben a kapszaicinkezelés hatására eltû́nik a primer afferens idegrostokból a SP-immunjelölödés, csökken a TNF $\alpha$ - és az IFN $\gamma$-szint, fokozódik a gyulladásgátló citokinek termelése. Klinikai vizsgálatok-

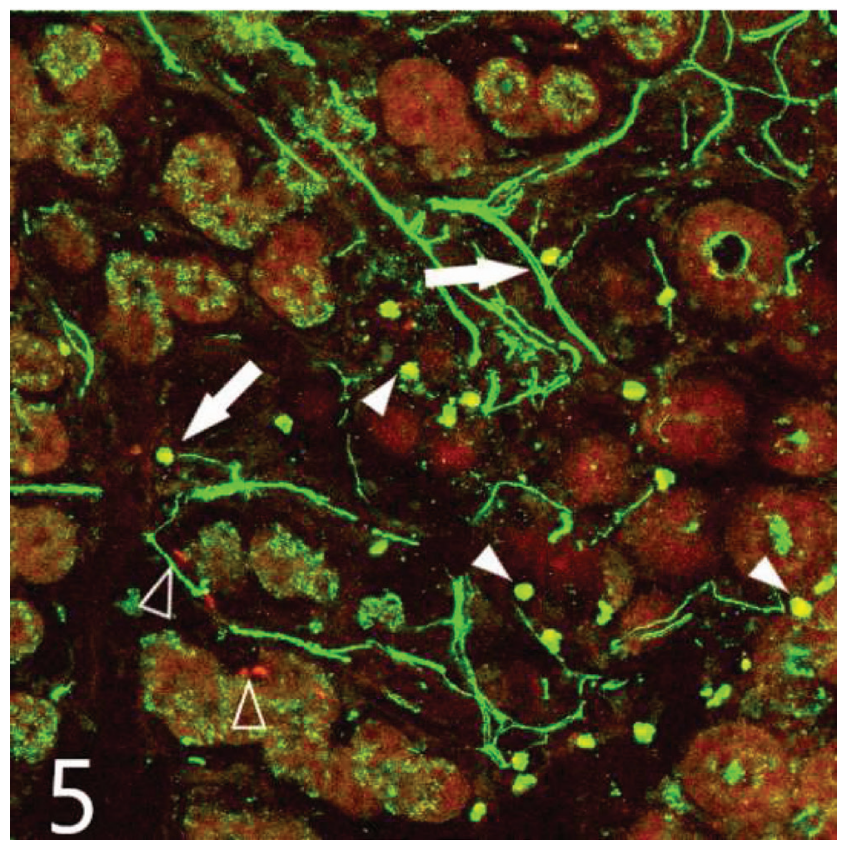

\begin{tabular}{l|l} 
5. ábra & Konfokális lézermikroszkópos kép sztreptozotocinnal indukált
\end{tabular} diabetes mellitusos vékonybél nyálkahártyájából. Nyilak jelzik a SP-pozitív idegrostokat a Lieberkühn-kripták között. Telt nyílhegyek mutatják a SP- és TNF $\alpha$-immunreaktivitást mutató lymphocytákat, ahol kolokalizálva fordul elő a két anyag. Üres nyílhegy jelzi azon lymphocytákat, melyek nem tartalmaznak SP-t

$\mathrm{SP}=$ substance $\mathrm{P} ; \mathrm{TNF} \alpha=$ tumornekrózisfaktor-alfa

kal is bizonyították a gyomor-bél csatorna gyulladásos betegségeinek javulását SP-antagonisták alkalmazásával [26-28]. Számos irodalmi adat bizonyítja: a TNF $\alpha$ elleni antitest alkalmazásával csökkenthető a rheumatoid arthritis és az emésztőrendszer gyulladásos folyamatainak aktiválása $[29,30]$. Számos irodalmi adat alátámasztja a NPY gyulladáscsökkentő hatását: azáltal, hogy modulálja a hízósejtek hisztamintermelését [31, 32] és a lymphocyták citokinfelszabadítását. NPY- és Y-receptor-specifikus anyagok alkalmazásakor állatkísérletben sikerült csökkenteni a gyulladást: Dimitrijević és mtsai [33, 34]. Hasonló eredmények érhetők el VIP alkalmazásával, ahol bizonyították a VIP peptid antiinflammatorikus hatását egereknél kísérletes colitisben [35-37]. A legutóbbi irodalmi adatok alapján feltételezhetó, hogy a PACAP és a VIP alkalmazása új terápiás lehetőséget jelent az immunhomeosztázis visszaállítására, az akut és krónikus gyulladásos folyamatok kezelésére [38-40].

Anyagi támogatás: A közlemény megírása anyagi támogatásban nem részesült.

Szerzôi munkamegosztás: F. E.: A kutatás irányítása, szakértői feladat ellátása. A szakirodalom felkutatása, elemzése, az összefoglaló közlemény megírása. A. K.: Irodalom keresése és az ábrák elkészítése. A cikk végleges változatát mindkét szerző elolvasta és jóváhagyta.

Érdekeltségek: A szerzőknek nincsenek érdekeltségeik. 


\section{Irodalom}

[1] Collins SM, Biennerhassett P, Vermillion DL, et al. The immu nomodulation of enteric neuromuscular function: implications for motility and inflammatory disorders. Gastroenterology 1996; 111: 1683-1699.

[2] Fehér E, Batbayar B, Vér Á, et al. Changes of the different neuropeptide-containing nerve fibres and immunocells in the diabetic rat's alimentary tract. Ann N Y Acad Sci. 2006; 1084 280-295.

[3] Pongor É, Fehér E, Lászik A, et al. Changes of the different neuropeptide containing nerve elements in the inflamed human gall bladder. [A különböző neuropeptidtartalmú idegelemek számának változása humán gyulladt epehólyagban.] Orv Hetil. 2006; 147: 1513-1518. [Hungarian]

[4] Taylor CT, Keely S. The autonomic nervous system and inflam matory bowel disease. Auton Neurosci. 2007; 133: 104-114.

[5] Villanacci V, Bassotti G, Nascimbeni R, et al. Enteric nervous system abnormalities in inflammatory bowel disease. Neurogastroenterol Motil. 2008; 20: 1009-1016

[6] Yoo BB, Mazmanian SK. The enteric network interactions be tween the immune and nervous systems of the gut. Immunity 2017; 46: 910-926

[7] Holzer P. Local effector functions of capsaicin sensory nerve endings involvement of tachykinins, calcitonin gene-related peptide and other neuropeptides. Neuroscience 1988; 24: 739-768.

[8] Holzer P. Efferent-like roles of afferent neurons in the gut: blood flows regulation and tissue protection. Auton Neurosci. 2006; 125: 70-75.

[9] Hökfelt T, Shaibe HG, Schmidt RF. Neuropeptides. Nocicption and pain. Chapman and Hall, Weinheim, 1994.

[10] Yasuda H, Terada M, Maeda K, et al. Diabetic neuropathy and nerve regeneration. Prog Neurobiol. 2003; 69: 229-285.

[11] Ho WZ, Kaufman D, Uvaydova M, et al. Substance P augments interleukin-10 and tumor necrosis factor- $\alpha$ release by human cord blood monocytes and macrophages. J Neuroimmunol. 1996; 71: 73-80.

[12] O'Connor TM, O'Connell J, O'Brien DI, et al. The role of substance $\mathrm{P}$ in inflammatory disease. J Cell Physiol. 2004; 201: $167-180$

[13] Fehér E, Kovács Á, Gallatz K, et al. Direct morphological evidence of neuroimmunomodulation in human colonic mucosa with Crohn's disease. Neuroimmunomodulation 1997; 4: 250257

[14] Lai JP, Douglas SD, Ho WZ. Human lymphocytes express substance $\mathrm{P}$ and its receptor. J Neuroimmunol. 1998; 86: 80-86.

[15] Fehér E, Altdorfer K, Bagaméri G, et al. Neruoimmune interactions in experimental colitis. Neuroimmunomodulation 2001; 9 247-255

[16] Fehér E, Pongor É, Altdorfer K, et al. Neuroimmunomodulation in human autoimmun liver disease. Cell Tissue Res. 2013; 354 $543-555$.

[17] Weinstock JV. Substance P and the regulation of inflammation in infections and inflammatory bowel disease. Acta Physiol (Oxf). 2015; 213: 453-461.

[18] Kispélyi B, Lohinai Z., Altdorfer K, et al. Neuropeptide analysis on oral mucosa of diabetic rats. Neuroimmunomodulation 2014; $21: 213-220$

[19] Pongor É, Altdorfer K, Fehér E. Colocalization of substance P with tumor necrosis factor- $\alpha$ in the lymphocytes and mast cells in gastritis in experimental rats. Inflammation Res. 2011; 60: 163168.

[20] Sipos G, Sipos P, Altdorfer K, et al. Correlation and immunolocalization of substance $P$ nerve fibres and activated immune cells in human chronic gastritis. Anat Rec. 2008; 291: 1140-1148.

[21] Sipos G, Altdorfer K, Pongor E, et al. Neuroimmune link in the mucosa of chronic gastritis with Helicobacter pylori infection. Dig Dis Sci. 2006; 51: 1810-1817.
[22] Lieb K, Fiebich BL, Berger M, et al. The neuropeptide substance $\mathrm{P}$ activates transcription factor NF-kappa B and kappa B-dependent gene expression in human astrocytoma cells. J Immunol. 1997; 150: 4952-4958.

[23] Blackwell TS, Blackwell TR, Christman JW. Impaired activation of nuclear factor-kappaB in endotoxin-tolerant rats is associated with down-regulation of chemokine gene expression and inhibition of neutrophilic lung inflammation. J Immunol. 1997; 158: 5934-5940.

[24] Ellis RD, Goodland JR, Kimb GA, et al. Activation of nuclear factor kappa B in Crohn's disease. Inflamm Res. 1998; 47: 440445 .

[25] Gad M, Pederson AE, Kristensen NN, et al. Blockage of the neurokinin 1 receptor and capsaicin-induced ablation of the enteric afferent nerves protect SCID mice against T-cell-induced chronic colitis. Inflamm Bowel Dis. 2009; 15: 1174-1182.

[26] Kataeva G, Agro A, Stanisz AM. Substance P-mediated intestinal inflammation inhibitory effects of CP 96,345 and SMS 201-995. Neuroimmunomodulation 1994; 1: 350-356.

[27] Sonea IM, Palmer MV, Akili D, et al. Treatment with neurokinin-1 receptor antagonist reduces severity of inflammatory bowel disease induced by Cryptosporidium parvum. Clin Diagn. Lab Immunol. 2002; 9: 333-340.

[28] Frieri M. Neuroimmunology and inflammation implications for therapy of allergic and autoimmune diseases. Ann Allergy Asth ma Immun. 2003; 90(Suppl 3): 34-40.

[29] Elliott MJ, Maini RN, Feldmann M, et al. Randomised double blind comparison of chimeric monoclonal antibody to tumor necrosis factor $\alpha$ (cA2) versus placebo in rheumatoid arthritis. Lancet 1994; 334: 1105-1110.

[30] Saud B, Nandi J, Ong G, et al. Inhibition of TNF- $\alpha$ improves indomethacin-induced enteropathy in rats by modulating iNOS expression. Dig Dis Sci. 2005; 50: 1677-1683.

[31] Bedui S, Kawamuira N, Straub RH, et al. Relevance of neuropeptide Y for the neuroimmune crosstalk. J Neuroimmunol. 2003; 134: 1-11.

[32] Bedui S, Kromer A, Gebbardt T, et al. Neuropeptide Y receptor specifically modulates molecules human neutrophyl function. J Neuroimmunol. 2008; 195: 88-95.

[33] Wheway J, Herzog H, Matkay F. NPY and receptors in immune and inflammatory diseases. Curr Top Med Chem. 2007; 7: 1743-1752.

[34] Dimitrijević, Stanojević, Mitić K, et al. The anti-inflammatory effect of neuropeptide Y (NPY) in rats is dependent on dipeptidyl peptidase 4 (DP4) activity and age. Peptides 2008; 29: 2179-2187.

[35] Gomaritz RP, Martinez C, Abad C, et al. Immunology of VIP: a review and therapeutical perspectives (Review). Curr Pharm. 2001; 7: 89-111.

[36] Delgado M, Abad C, Martinez C, et al. PACAP in immunity and inflammation. Ann New York Acad Sci. 2003; 992: 141-157.

[37] Arranz A, Abad C, Juarranz Y, et al. Vasoactive intestinal peptide as a healing mediator in Chron's disease. Neuroimmunomodulation 2008 ; 15: 46-53.

[38] Abad C, Martinez C, Juarranz MG, et al. Therapeutic effects of vasoactive intestinal peptide in the trinitrobenzene sulfonic acid mice model of Crohn's disease. Gastroenterology 2003; 124: 961-971

[39] Gonzalez-Rey E, Delgado M. Vasoactive intestinal peptide and regulatory T-cell induction: a new mechanism and therapeutic potential for immune homeostais. Trends Mol Med. 2007; 13: 24l-25l.

[40] Abad C, Yossan-Var T. Immunomodulatory roles of PACAP and VIP: lessons from knockout mice. J Mol Neurosci. 2018; 66: $102-113$

(Fehér Erzsébet dr., Budapest, Túzoltó u. 58., 1094 e-mail: feher.erzsebet@med.semmelweis-univ.hu)

A cikk a Creative Commons Attribution 4.0 International License (https://creativecommons.org/licenses/by/4.0/) feltételei szerint publikált Open Access közlemény. (SID_1) 